\title{
Performance Assessment of Screw Piles Embedded in Soft Clay
}

\author{
Omar K. Ali ${ }^{a^{*}}$, Hassan O. Abbas ${ }^{b}$ \\ ${ }^{a}$ M.Sc. Student, College of Engineering, University of Diyala, Baqubah, Daiyla, Iraq. \\ ${ }^{b}$ Assistant Professor, College of Engineering, University of Diyala, Baqubah, Daiyla, Iraq. \\ Received 07 April 2019; Accepted 02 July 2019
}

\begin{abstract}
Screw piles are widely used in a variety engineering applications supplying stability against compression, overturning moment, uplift tension, and horizontal loads. Screw pile is a famous solution for support light structures, roads and rail signs which have relatively low-capacity foundation. In this study, the behavior of circular (10) $\mathrm{mm}$ solid screw pile models embedded in a bed of soft clay soil covering a layer of sandy soil has been studied. The $200 \mathrm{~mm}$ thick sand layer was compacted in a steel container with a diameter of $300 \mathrm{~mm}$ into four sublayers. The sandy soil layer was compacted at a relative density of $70 \%$. The $300 \mathrm{~mm}$ thick soft clay soil bed with $\mathrm{Cu}(30) \mathrm{kPa}$ was compacted in six sub-layers on the sandy bottom layer. Model tests are carried out with screw piles with a length of $300 \mathrm{~mm}, 350 \mathrm{~mm}$ and $400 \mathrm{~mm}$ and a helix diameter of $30 \mathrm{~mm}$. Also, single and double helix and different $\mathrm{S} / \mathrm{Dh}$ ratio were used for these piles and a comparative study between screw piles and ordinary piles (without helices) is accomplished. This study revealed that introducing screw pile of double helix increases its bearing capacity in soft clay soil by up to a (4-8) \% as compared to a single helix screw pile. The results showed that the behavior of screw pile essentially depends on the geometric properties of the pile. According to the achievements, compressive load capacity of screw piles depends on embedded length, spacing ratio (S/Dh) and number of helical plates.
\end{abstract}

Keywords: Screw Pile; Soft Clay; Cylindrical Shear; Compressive Axial Loading; Helix Plate.

\section{Introduction}

Soft clay soils are recent alluvial deposits, probably formed over the past 10,000 years described by their flat, featureless surface, Brand and Brenner (1981), British Standard (1986) [1, 2]. These soils are identified by their high compressibility (Cc between 0.19 and 0.44) and their low undrained shear strength $(\mathrm{Cu}<40 \mathrm{kPa})$, British Standard (1986) [2]. In general, soft clay soils are stiff when dry and loss this property when become wet. Leakage of sewer lines, floods, rains and lack of evaporation due to buildings or pavements are the popular reasons of increasing moisture content in clayey soils [3]. The soils which have such characteristics causes several problems to geotechnical engineering associated with low bearing capacity, settlements and stability problems.

Pile foundations are the Structure's part that carried and transferred the superstructure load to the bearing ground at a certain depth below the ground surface. Piles are long and thin element that transfer the load through weak, compressible layers or water into deeper soil or rock of high bearing capacity and less compressibility to avoid shallow soil of low bearing capacity [4]. Pile foundations in more conventional civil engineering applications have a wide range of types and sizes and materials are used in practice. A lot of research has been done to find the appropriate type of piles for different geotechnical and structural conditions. First, the shape of the pile was a simple shaft, then it evolved over

* Corresponding author: eng.omaralzuhairy88@yahoo.com

http://dx.doi.org/10.28991/cej-2019-03091371

(C) 2019 by the authors. Licensee C.E.J, Tehran, Iran. This article is an open access article distributed under the terms and conditions of the Creative Commons Attribution (CC-BY) license (http://creativecommons.org/licenses/by/4.0/). 
time to adopt complex shapes similar to those that are now used: Franki piles, Omega piles, Fundex piles, drilled piles (CFA), Atlas piles, screw piles and etc. [5]. With construction design challenges and ever-increasing demands for sustainable practices and cost-saving solutions, the construction industry is looking for foundations that offer efficient construction techniques, innovative pile configurations, and novel materials applications.

Owing to their many construction advantages, screw piles are gaining in popularity, especially in projects requiring quick installation and loading of the foundation [6]. Now a day, screw pile foundations have become popular in many countries. The use of screw piles as a deep foundation option has increased significantly in recent years to support various loads, from small loads for multiple applications such as residential housing, solar farms, utilities and renovation projects loads for many applications such as commercial lines, power transmission lines, oil installations and industrial applications [7]. Screw piles are called helical piles or helical anchors, or are structural and deep foundation members used to provide stability to compressive, tension and lateral loadings [8]. Screw piles consist of a steel shaft, either a solid square shaft or a circular tube with one or more helix attached to it [9]. The screw pile design implies the choice of its shaft length and the diameter and a specific arrangement of helices including their number, their diameter (Dh), the ratio of helix spacing over helix diameter $(\mathrm{S} / \mathrm{Dh})$ and the embedment depth to helix diameter ratio $(\mathrm{L} / \mathrm{Dh})$ of the upper helix. All of these parameters can be influenced on the ultimate capacity of screw pile [10]. On account of the relatively simple installation process compared to traditional deep foundations (e.g. drilling and bored piles) and increasing acceptance in the geotechnical industry, the popularity of screw piles has risen sharply in recent decades. The screw pile like any deep foundation, must embed and transfer load through the active area to a stable ground below. The active area is defined as the area or Depth of seasonal moisture restoration, sometimes called wetting depth. It is the depth or area where the forces of expansion or shrinkage of the soil have an adverse effect on the depth [11]. Screw piles differ from conventional piles in that they are usually made of high strength steel consisting of helices fixed to the shaft at spaced intervals and having a pointed tip to allow for better installation in the ground [12]. There are various dimensions of screw piles that are specific to certain conditions, among which shaft and helical plate diameters, helix pitches, spacing between helical plates and embedment depths are differential points. The screw piles were initially used primarily as anchors, and therefore focused on tensile loads such as transmission tower sand buried pipelines. However, their use has been extended to structures that are subject to compressive, tension and lateral loading [13].

The screw pile system is not suitable for the foundation in gravely or stiff soil, as the helix plates can be damaged during the process of pile installation. Failure due to axial loading of the screw piles can occur either in individual plate bearing or cylindrical shear model. The type of failure can therefore affect the behavior of the piles and their capacity [14]. Screw piles have become the focus of experimental studies in Geotechnical laboratories are studying the resistance to compressive or pull-out forces and the behavior of these piles under axial loads from the structure itself. Screw piles also have good tensile and compressive capacity ( 2 to 3 times the capacity of a conventional pile [15] and can be used for a variety of soil layers above and below water.

Soft clay soil covers vast areas of the central and southern governorates of Iraq. Soil profile in these areas consist from large depth of soft clay overlaying sandy soil. In such soils, there are substantial difficulties associated with geotechnical design and the implementation of civil engineering structures, difficulties and problems require the use of efficient, efficient and inexpensive solutions, as well as the old buildings are damaged due to the recent earthquakes, And the reconstruction that will be accepted by the country was to be thought of solutions meet all these requirements, which include the use of screw piles, which are characterized by fast and easy installation and multiple uses and low cost and high efficiency.

This paper presents the behavior of screw piles in soft clay soils has focused predominantly on the behavior of multihelix screw piles loaded in axial compression with varying embedment depth, , number of helix plate, helical plate spacing ratio, S/Dh, and pile length, $\mathrm{L}$, as defined in Figure 1. 


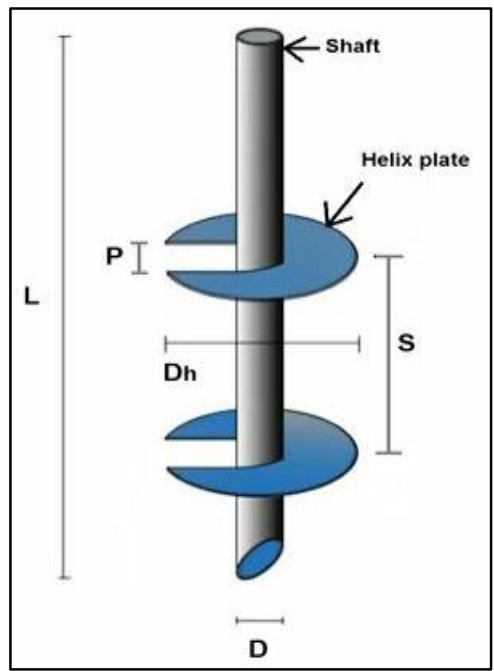

Figure 1. The geometry of screw pile

\section{Materials}

\subsection{Soft Clay Soil}

The soil used in this study was brought from Baquba Brick Factory Workers village within Diyala governorate, Iraq from a depth of two meters from natural ground level. Before the soil preparation stage, trial tests were conducted to control the efficiency of the preparation method. Control tests were performed to determine the variation in shear strength at different water contents (or at different liquidity indices) several trails were made and typical results are showed in Figure 2. The laboratory test results are presented in Table 1. According to the ASTM - standard classification for soil, the soil is classified as (CL).

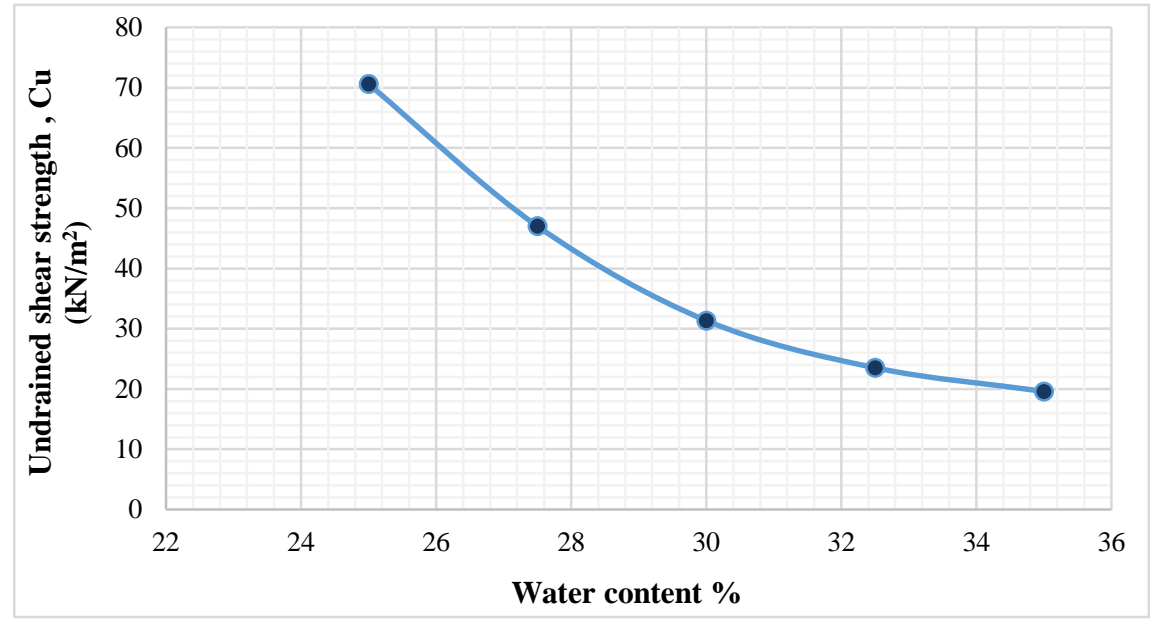

Figure 2. Variation of undrained shear strength versus water content for the remolded clay after 48 hrs.

Table 1. Physical properties of soft clay soil

\begin{tabular}{clcl}
\hline Item & Property & Value & Specification \\
\hline 1 & Specific gravity (Gs) & 2.84 & ASTM D 854 - 2 \\
2 & Liquid limit (L.L)\% & 38.5 & ASTM D 4318 - 00 \\
3 & Plastic limit (P.L)\% & 23.3 & ASTM D 4318 - 00 \\
4 & Plasticity Index (I.P)\% & 15.2 & \\
5 & Clay \% & 51 & ASTM D 422 \\
6 & Silt\% & 45.7 & ASTM D 422 \\
7 & Sand\% & 3.3 & ASTM D 422 \\
8 & Unified Soil Classification System (USCS) & CL & ASTM D 422 \\
9 & Maximum Unit Weight (kN/m $\left.{ }^{3}\right)$ & 17.8 & (ASTM D-1557) \\
10 & Optimum Moisture Content (O.M.C)\% & 18 & ASTM D-1557) \\
\hline
\end{tabular}




\subsection{Sandy Soil}

This soil is used under soft clay soil, which serves as a stable zone, Fine clean sand from the Karbala Governorate site south of the city of Baghdad in Iraq. Before the testing stage, the sandy soil is dried in the laboratory for 24 hours at $105^{\circ} \mathrm{C}$ in a drying oven. Then sieved on No.40 sieve to remove the coarse particles. Laboratory tests were carried out on the sandy soil to determine the physical and mechanical, properties. The laboratory test results are shown in Table 2. Here should be mentioned; the direct shear test was carried out at a relative density of $70 \%$, which corresponds to (16) $\mathrm{kN} / \mathrm{m}^{3}$ dry unit weight. According to the ASTM standard classification for soil, the soil is classified as poorly graded sand (SP).

Table 2. Summary of properties of sandy soils

\begin{tabular}{clcc}
\hline Item & Property & Value & Specification \\
\hline 1 & Coefficient of Uniformity $(\mathrm{Cu})$ & 2.6 & (ASTM D-422) and ASTM D 2487 (2006) \\
2 & Coefficient of Curvature (Cc) & 0.84 & (ASTM D-422) and ASTM D 2487 (2006) \\
3 & Unified Soil Classification System (USCS) & SP & (ASTM D-422) and ASTM D 2487 (2006) \\
4 & Specific Gravity (Gas) & 2.63 & \\
5 & Cohesion $(\mathrm{kN} / \mathrm{m} 2)$ & 0 & ASTM D3040-04(2006) \\
6 & Angle of Internal Friction $\left(\varphi^{\circ}\right)$ & 35.79 & ASTM D3040-04(2006) \\
\hline
\end{tabular}

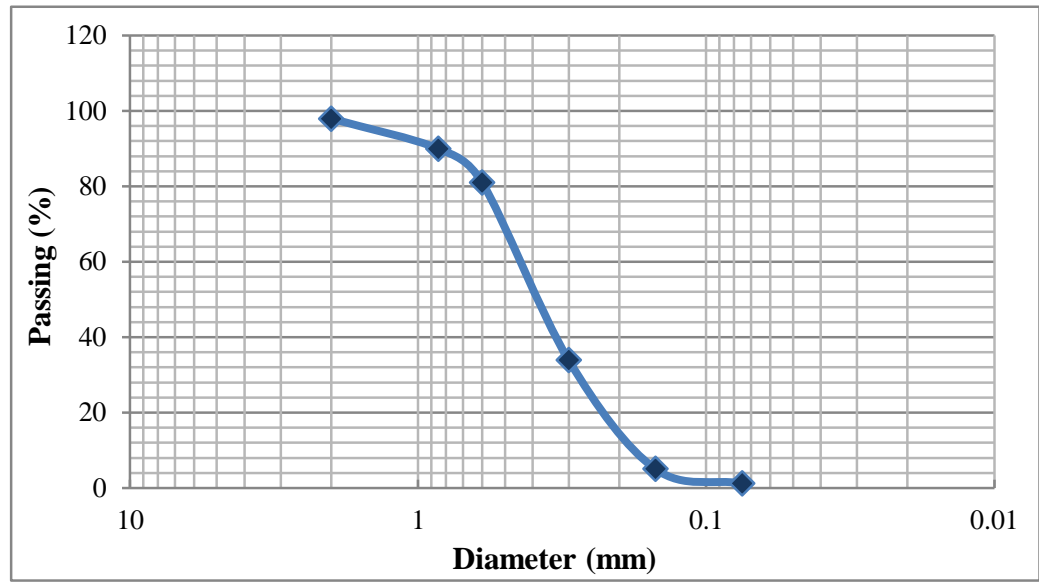

Figure 3. Grain Size Distribution Curve of sandy soil

\subsection{Model Piles}

Twelve steel screw piles with a length of 300, 350 and $400 \mathrm{~mm}$ and a circular solid section with a diameter of 10 $\mathrm{mm}$ were made of high-strength steel. The diameter of helix plate $\left(\mathrm{D}_{\mathrm{h}}\right)$ are used $30 \mathrm{~mm}$ with thickness $2 \mathrm{~mm}$ and a helical plate pitch (p) of $10 \mathrm{~mm}$. The helix plate were manufactured from steel and welded firmly and accurately to the pile shaft. Two spacing are used $30 \mathrm{~mm}\left(S=D_{h}\right)$ and $50 \mathrm{~mm}\left(S=1.6 D_{h}\right)$. Figure 4 shows screw pile geometry. The termination of the shaft was a $45 \%$ to aid keying during installation. The experimental program is carried out on single pile with different length, helical plate spacing and number of helical plate.

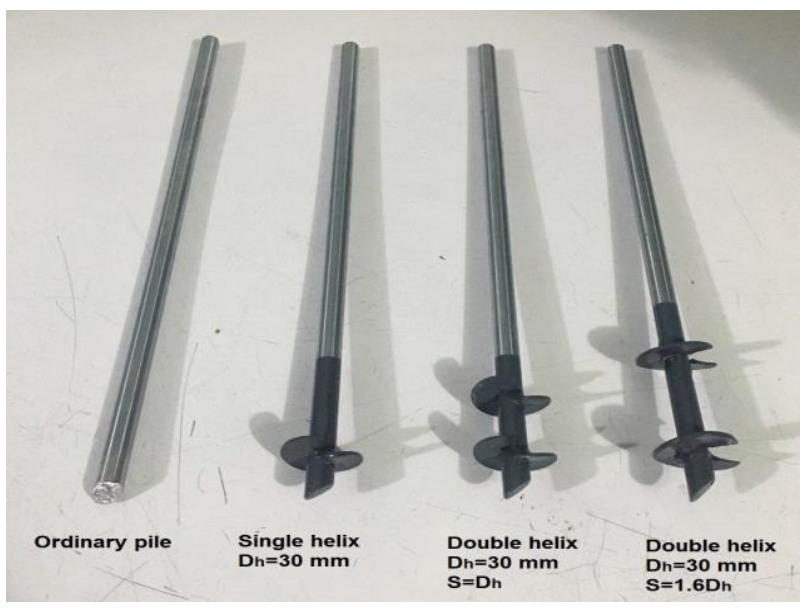

Figure 4. Different types of screw piles that were used in this study 


\subsection{Soil Container}

In general, the soil steel container (test tank) dimensions are determined based on the effectively stressed zone of soil mass from the foundation edge [16]. The steel soil container was manufactured using a $4 \mathrm{~mm}$ thick plate having an inner diameter of $30 \mathrm{~cm}$ and a height of $55 \mathrm{~cm}$. The base of the container is carried by four small wheels. The containers were painted with two layers of anti-rust paint and two layers of conductive base to withstand corrosion during the test period. Table 2 shows the container used in test models.

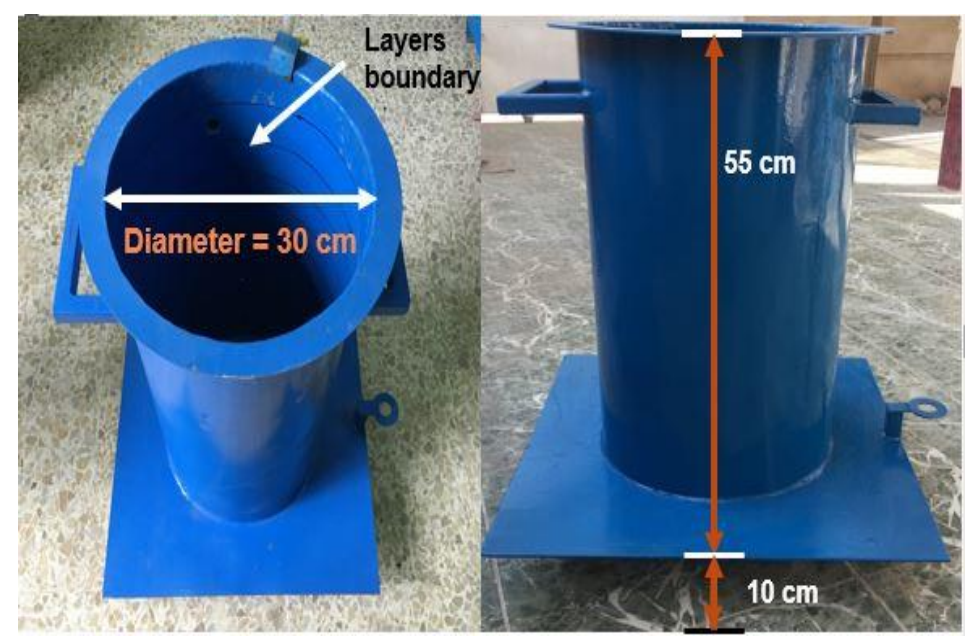

Figure 5. Soil container used in this study

\section{Testing Procedure}

Figure 6 shows the experimental program proposed for this study. The tests are conducted in the laboratory of civil engineering of the faculty of Engineering in Diyala University. After testing and soil preparation, self-design laboratory models, shown in Figures 8 and 10 are using respectively to process of pile installation and testing.

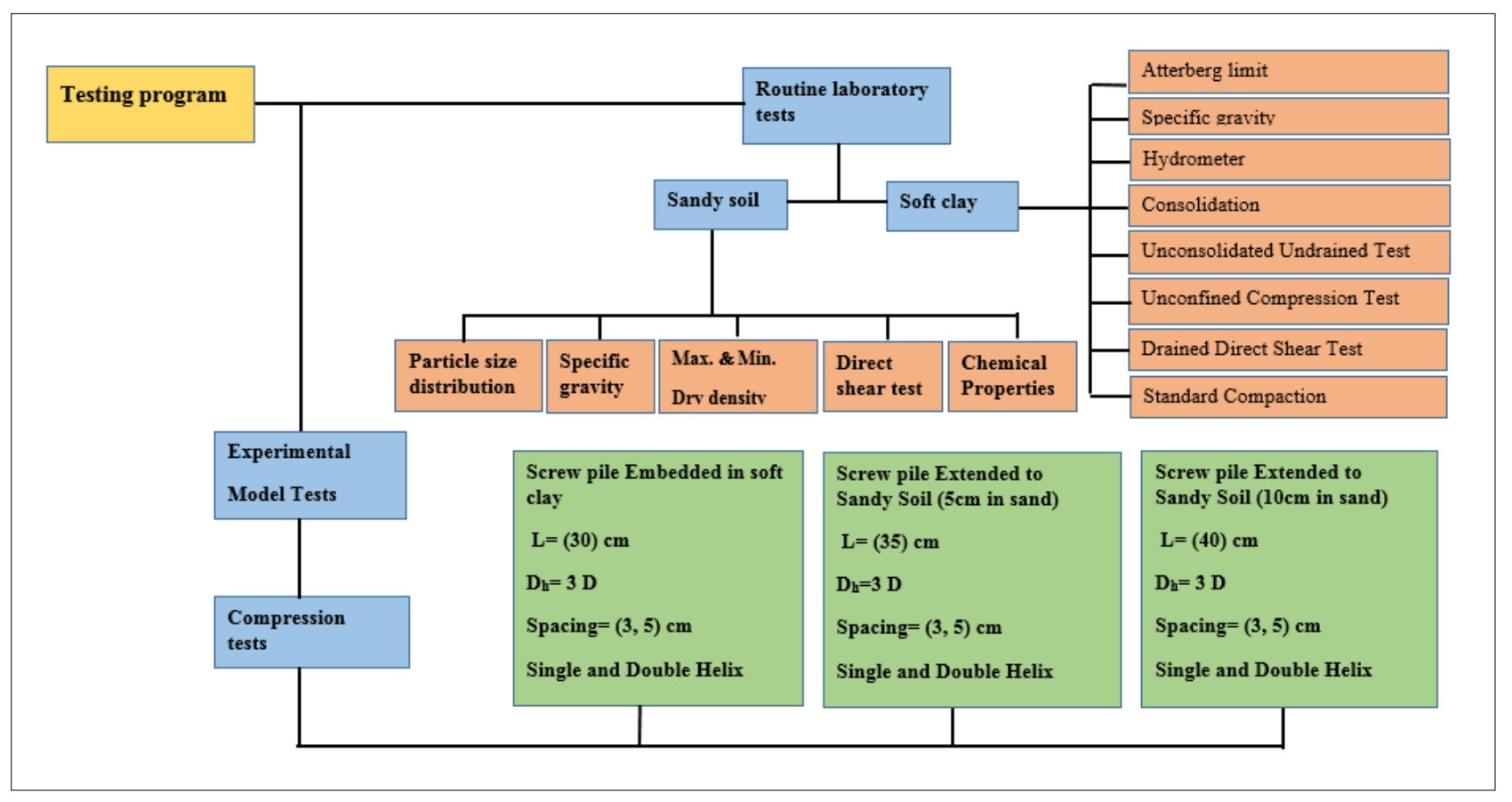

Figure 6. Flow chart of testing program

\subsection{Soil Preparation}

This stage begins after completions of the laboratory test required for the used soil in this study.

- Sandy Soil: The required amount of oven-dried natural sand soil passing through No. 40 sieve was prepared at a dry weight of $16 \mathrm{kN} / \mathrm{m} \mathrm{3}$, which corresponds to the dense state. Compaction is manually performed using a steel plate hammer $9.87 \mathrm{~kg}$ and of (150) mm diameter. 
- Soft Clay Soil: The soil bed was prepared at water content of $30 \%$ corresponding to cu=30kPa.Weight of $30 \mathrm{~kg}$ of natural soil was mixed with enough quantity of water to get the desired consistency. The operation of mixing was performed using electrical mixing; each $15 \mathrm{~kg}$ of dry soil was mixed separately till completing the whole quantity, as shown in Figure 7.

- After being thoroughly mixed, the soil was placed in six layers in a steel container; each layer was gently levelled with a wooden tamper and then the levelled layer was gently tamped with a manufactured steel plate hammer having a diameter of $9.87 \mathrm{~kg}$ and a diameter of (150) $\mathrm{mm}$ to remove any trapped air. This process continues for the six layers until reaching $500 \mathrm{~mm}$ of soil thickness in the steel container. After the final layer was finished, the top surface was levelled to obtain a flat surface as possible and then covered with polyethylene sheet for two days to achieve a uniform moisture content and prevent moisture loss.

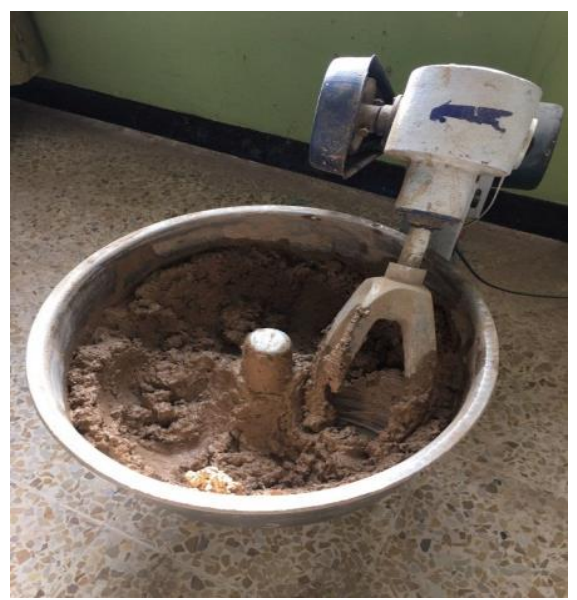

\subsection{Pile Installation}

Figure 7. Soil mixing device

The process of installing screw piles is considered to have an influence on the design. Installation in soils that are not detrimental to screw piles will generally not affect the design if standard installation procedures are followed [17]. The installation process conducted after the soil preparation. The model piles were screwed slowly into the ground by applying a torque with appropriate downward force.

The torque applied through the use of a hydraulic torque motor provided the rotational and vertical forces required to install screw pile in the centre of surface of soft clay soil bed to the depth required. The vertical speed and the number of revolutions per minute (rpm) depend on the pitch $(\mathrm{P})$ of the screw pile [18]. The installation of a screw pile must take place in such a way that the screw pile penetrates the ground in an amount equal to the pitch of the helix $(\mathrm{P})$ for each complete revolution in order to minimize the disturbance of the ground [19]. Thus, a controlled displacement installation with a penetration rate of $10 \mathrm{~mm} / \mathrm{min}$ and a rotational speed of $3.60 \mathrm{rpm}$ was used for all tests. Figure 8 shows that the hydraulic torque motor has been used in the driven screw pile.

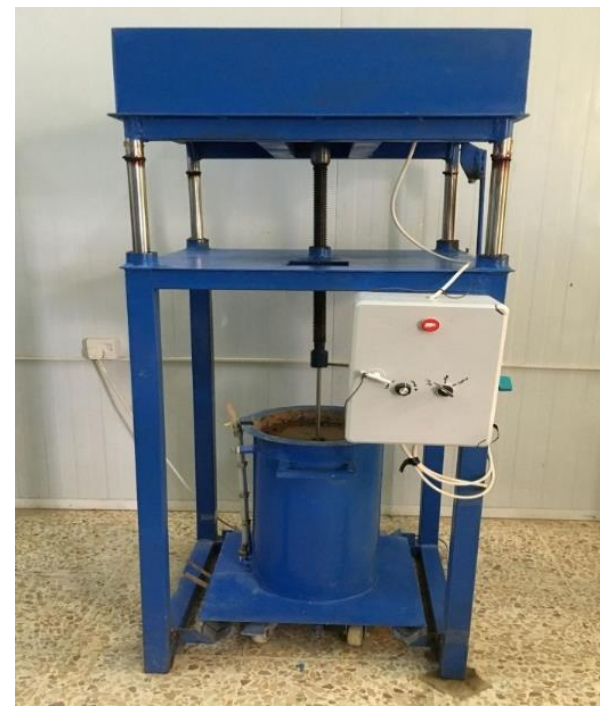

Figure 8. Hydraulic torque motor 


\subsection{Pile Load Test}

In loading cases, the axial compression load is applied to a screw pile through a 3 ton (S-shaped) load cell. Using timer with a constant load penetration rate of $0.5 \mathrm{~mm} / \mathrm{min}$ in the full test program based on ASTM (2018) standard D1143 for axial compression testing, which are concluded that the range of penetration rate $(0.25$ to $1.25 \mathrm{~mm}) / \mathrm{min}$ for cohesive soils $)$. The test is in progress recorded a continuous displacement of the single screw piles until of $(12 \mathrm{~mm})$ embedded depth. Figure 9 shown the loading versus time for double helix screw pile with $400 \mathrm{~mm}$ length, $\mathrm{Dh}=30 \mathrm{~mm}$ and s=30mm. The load is measured by a digital weighing indicator linked to the load cell. The central settlement of the screw piles cap is read by two digital dial gauge with $0.001 \mathrm{~mm}$ sensitivity. Figure 10 shows the pile test device.

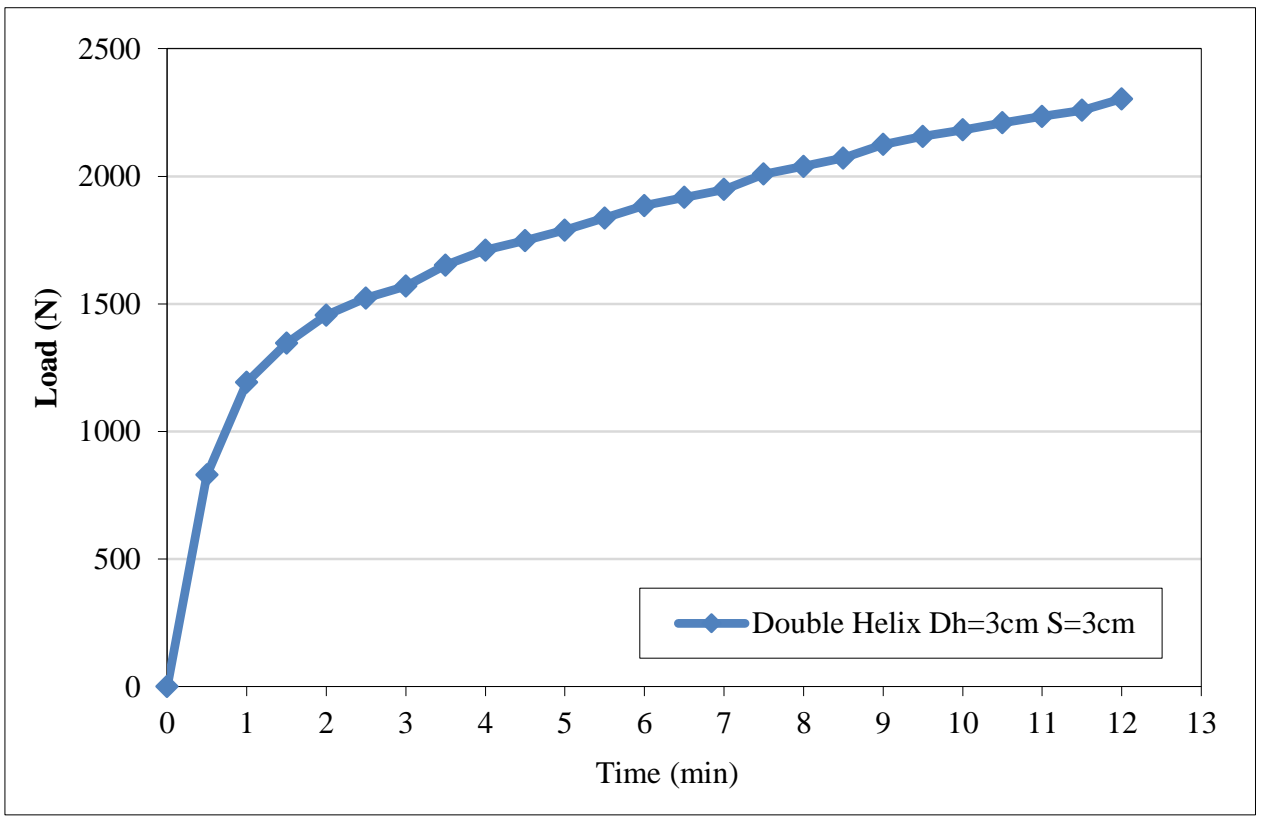

Figure 9. The load - time chart during the process of pile testing

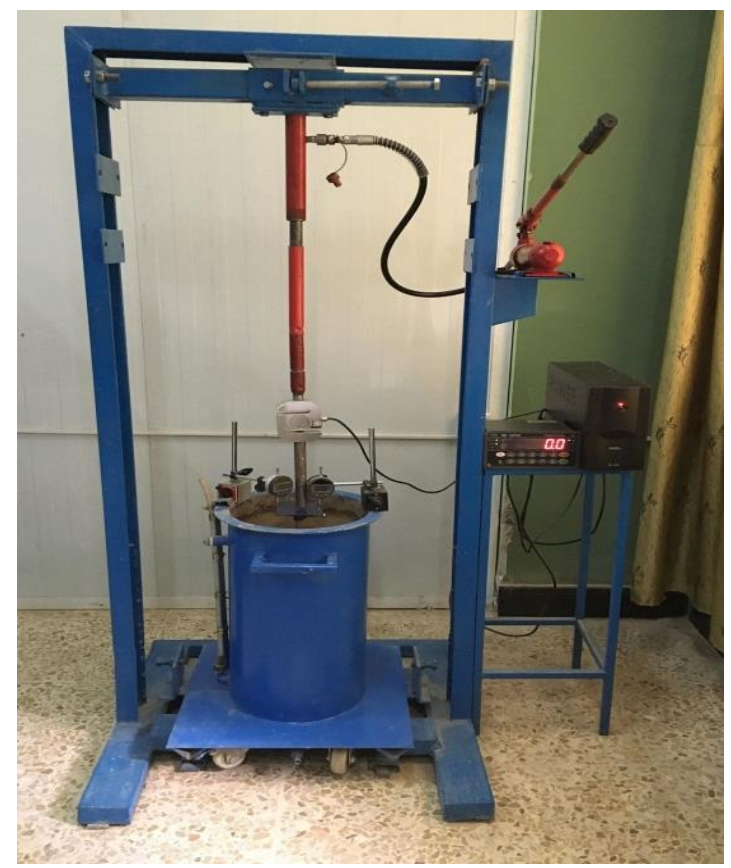

Figure 10. The device used in testing models

\section{Results and Discussions}

As the literature indicates, there are several failure criteria methods that predict the ultimate load bearing capacity of screw piles from a load test. Some of these methods are explained by Sakr (2011) [20]. As the Davisson criterion, Brinch Hansen criterion, L1-L2 method, Federal Highway Administration (FHWA) method (5\% of the diameter of helix) and ISSMFE (10\% of the diameter of helix). The last method, called ISSMFE, is to find the load at a displacement level of $10 \%$ of the helix plate 
diameter [21]. The last one was taken over in this investigation.

The behaviour of the screw pile can be better evaluated using the results obtained during compression load tests. Model tests are carried out on ordinary piles (steel pile without helix plates) and have the same circular cross section with diameter (10) $\mathrm{mm}$ of screw piles to compare the degree of efficiency with screw piles. Three different L/D ratio were used 30, 35 and 40, also single and double helix with different spacing between helix plates (s), $3 \mathrm{~cm}$ and $5 \mathrm{~cm}$ were used. Figure 11 shows the effect of the length of screw piles on its capacity. The increase of the L/D ratio for ordinary pile (steel pile without helix) and screw pile increases the compressive capacity, which is due to the anchoring of long piles in the deep soil layer. In general, the ultimate pile capacity increased with increasing its length, that's agree with Hamdy (2013) [22] who found that the compression load of screw pile carrying capacities increases with increasing the embedment ratio (L/D) from laboratory tests. In other words, for all piles, the application of the proposed failure criterion on the results led to conclusion that piles installed in soft clay over sandy soil had the greatest ultimate capacity regardless of other factors of pile geometry such as the number of helix and the spacing between the helix plates.

Figure 12 shows the variation of ultimate compressive load of ordinary piles and screw piles in soft clay soil embedded to sandy soil layer. It is clear from Figure 12 is that the ultimate compression force increased with increasing length of embedment of screw piles in sandy soil layer, number of helix and ratio of spacing between helix to helix diameter ( $\mathrm{S} / \mathrm{Dh})$. This is may be due to the effect of riveting action of screw piles and shear resistance mobilized along the circumference cylindrical and bearing of screw piles and soil.

In general, the screw piles of single and double helix plates have compression force (3.7-8) times more than ordinary pile (without helix plate ). The increase in compression forces are $(41,40,38,25)$ times when ratio of $\mathrm{Ls} / \mathrm{H}$ change from (o) to (0.33) for ordinary piles, single helix, double helix $(\mathrm{S} / \mathrm{Dh}=1)$ and double helix $(\mathrm{S} / \mathrm{Dh}=1.6)$ respectively. In other words, for all piles, the compression capacity of screw pile is strongly affected by the number of helix plate, and that's agree with Khazaei, Javad, and Abolfazl Eslami (2016) [14] who conclude that adding helix diameter will be very effective in improving the screw pile capacity.

According to the results, in the case of screw pile with double helices, the compression capacity mainly depends on spacing ratio $\mathrm{S} / \mathrm{Dh}$. In the current study screw piles by different spacing ratios were tested. 1 and $1.33 \mathrm{~S} / \mathrm{Dh}$ ratios were used. Figure 13 depicts the relation between spacing ratio $(\mathrm{S} / \mathrm{Dh})$ and ultimate compressive load for screw pile of double helix plates at different slenderness ratios. As mentioned above, the ultimate compressive force increases with increase slenderness ratio $(\mathrm{L} / \mathrm{D})$. Screw pile of spacing to helix diameter $(\mathrm{S} / \mathrm{Dh}=1)$ gave (1.4-3.4) times more than that of $(\mathrm{S} / \mathrm{Dh}=1.6)$ except at $\mathrm{L} / \mathrm{D}=30$ which gave approximately the same value. This may be attributed to the contact surface area between helix plates. This area is large at $(\mathrm{S} / \mathrm{Dh}=1)$ which gave high value of resistance to compression force. In other words, the compressive capacity of screw pile in dense sand decrease when S/Dh ratio increases from 1 to 1.33, also can be observed that the screw pile with single and double helix have a similar behaviour and have better value of compressive capacity in sand than soft clay and the reason could be higher resistance between helices plate and sand.

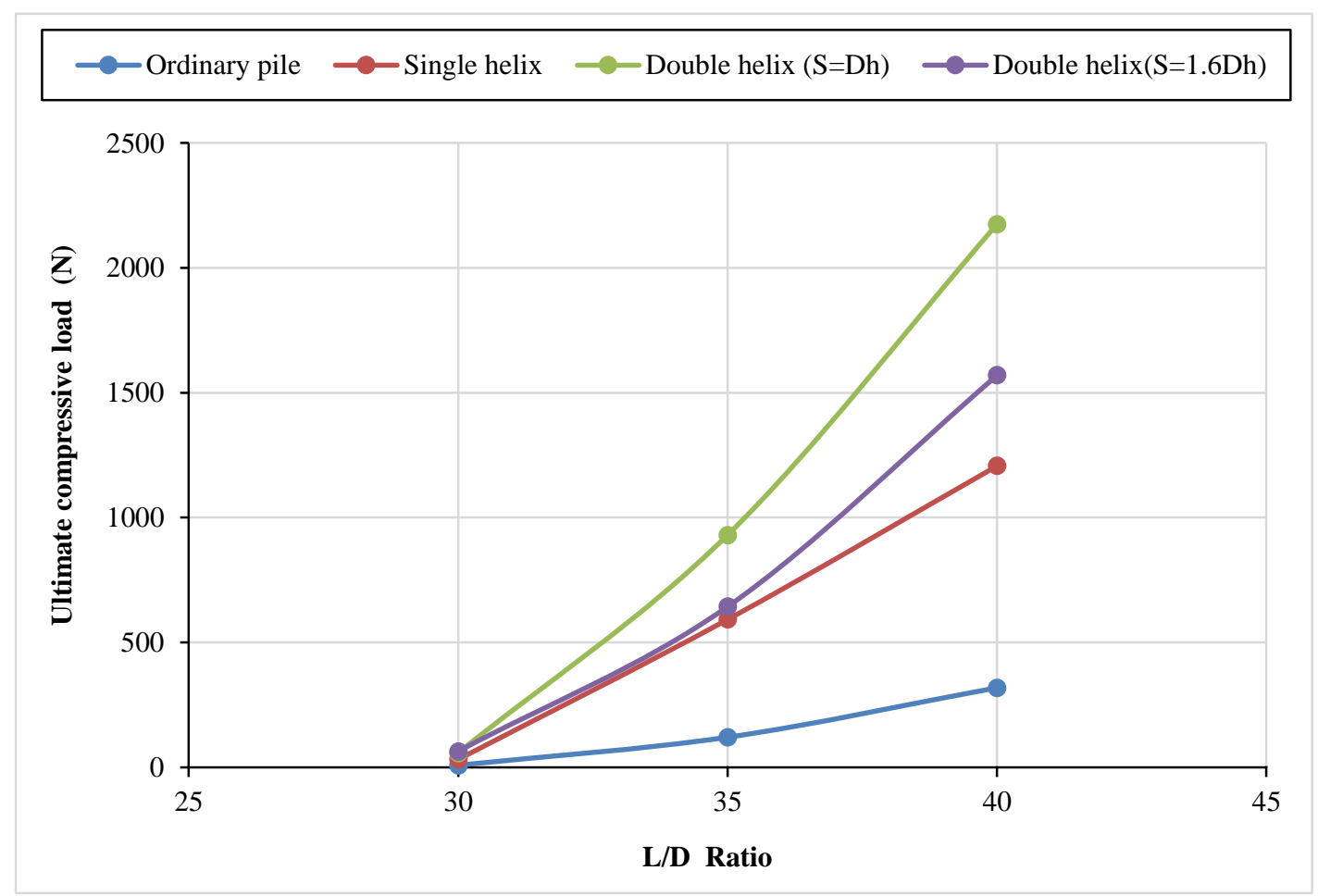

Figure 11. Variation of ultimate compressive load of screw pile with $L / D$ ratio for different lengths and helix diameters 


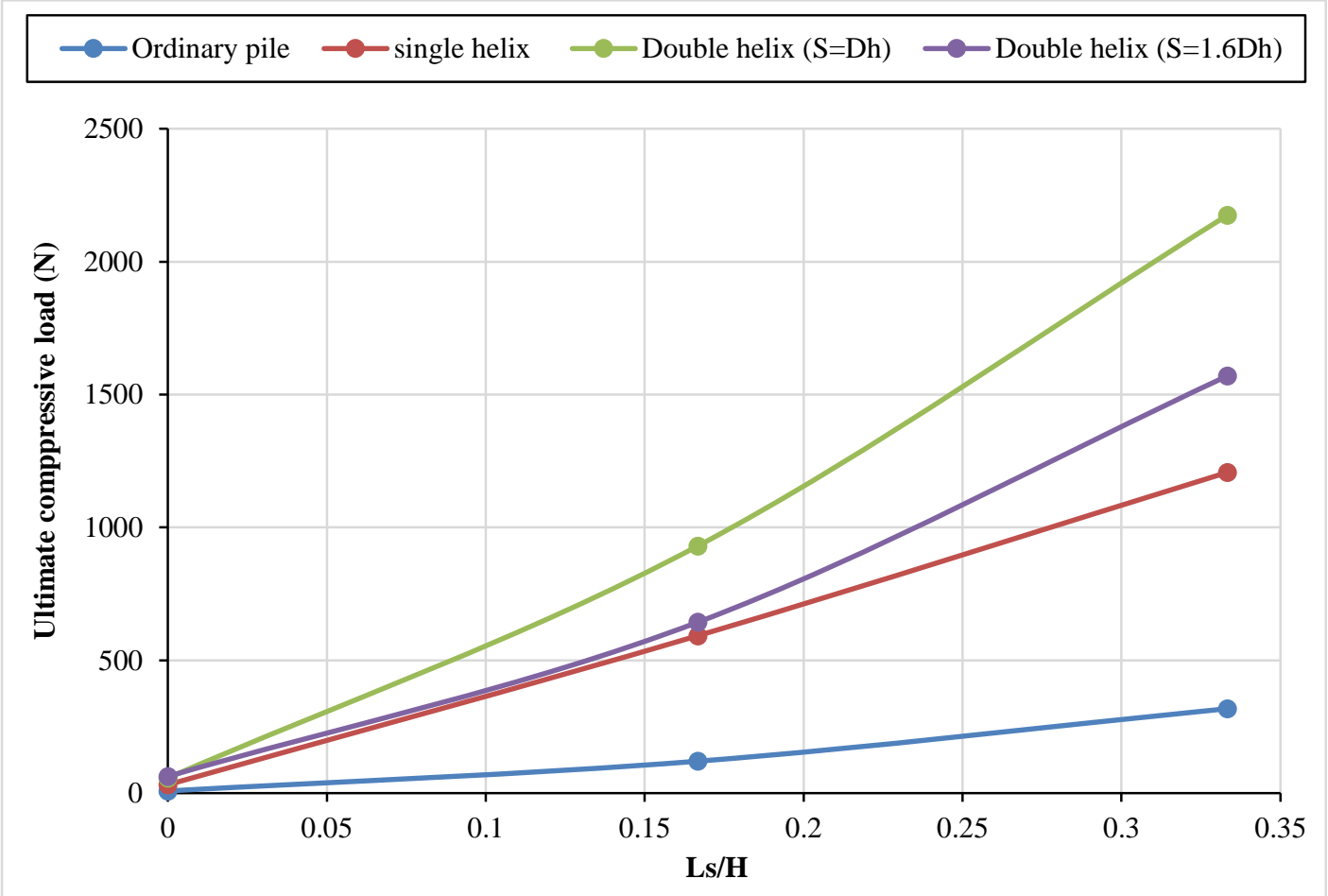

Figure 12. Variation of ultimate compressive load of ordinary pile and screw pile in soft clay soil embedded in sandy soil

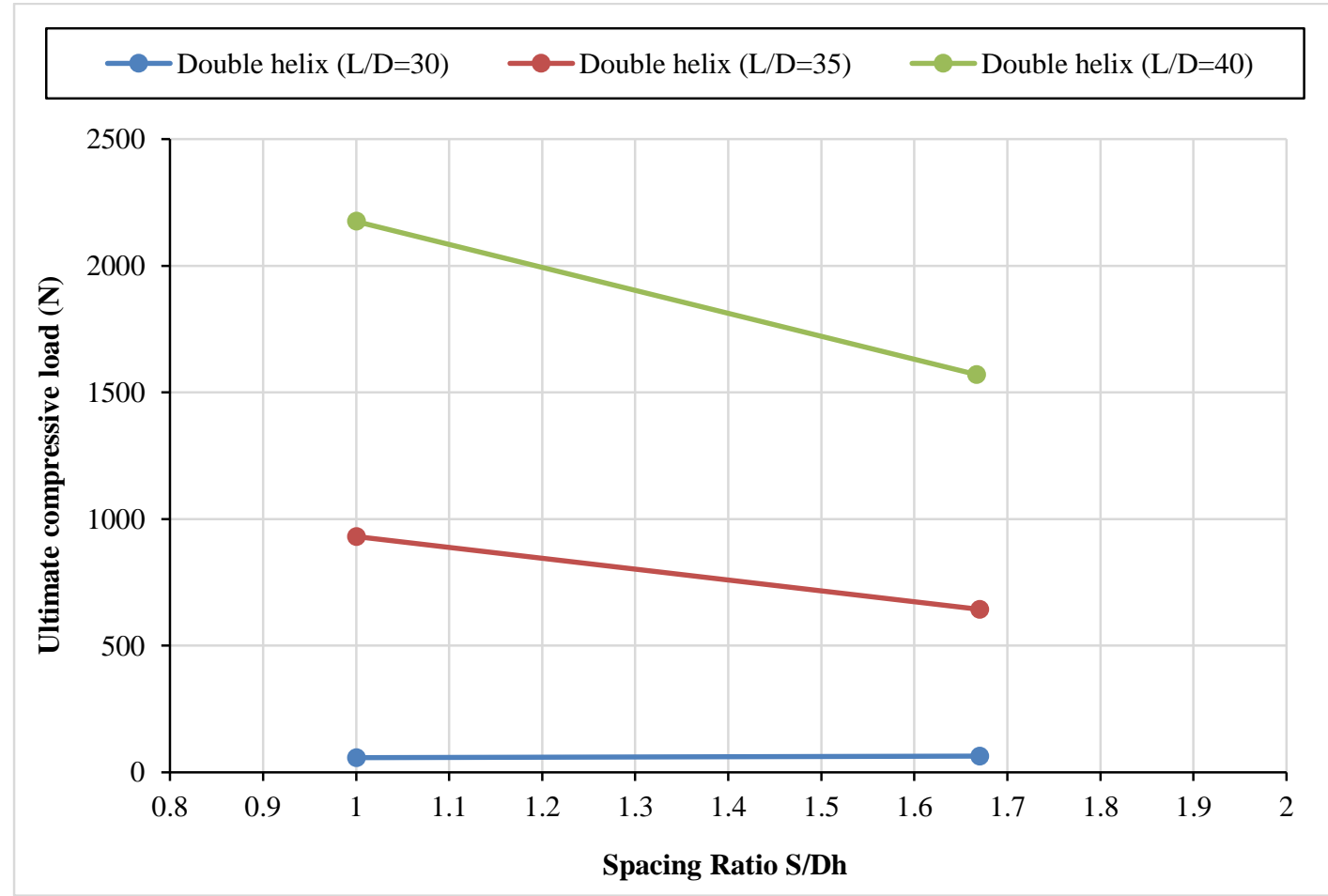

Figure 13. Variation of ultimate compressive load of screw pile with double helix with S/Dh ratio

The presence of helix plates in stable zone (sandy soil) leads to increase compression resistance of screw piles. This behaviour may be attributed to increase in surface area of part of screw pile embedded in sandy soil that cause increase in anchorage resistance.

It was noticed that the deeper screw pile with higher L/D ratios showed greater compression capacity than the shallower piles. Furthermore, screw pile showed more resistance to the applied compression than ordinary piles because of the presence of the helix plates which provides additional anchorage in deep soil layers. The compression force increase with increasing diameter of helices and number of helix plates.

The failure mode of screw piles is examined by cutting the soft clay soil and sandy soil after finish the test of screw pile under 
the compressive load as shown in Figure 14.

The results showed that the type of failure for screw pile with two helix is cylindrical shear surface which occurred in the region between two helix plates while individual helix failure occurred at the base of screw piles which has one helix.

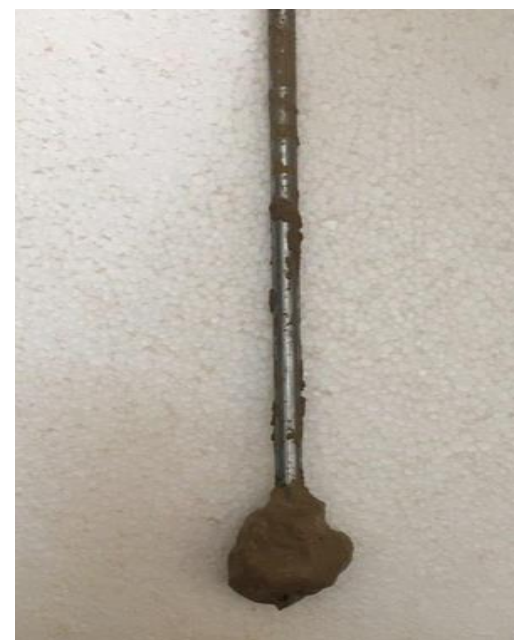

(a) Single helix plate

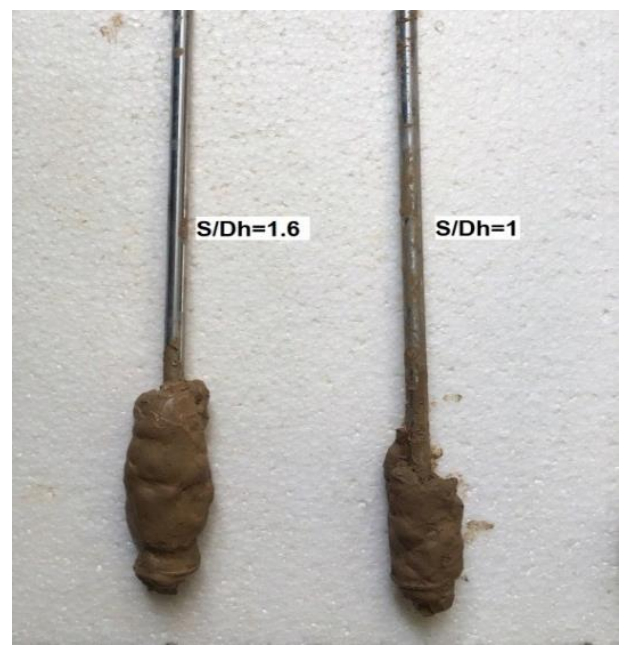

(b) Double helix plate

Figure 14. Failure mode type of single and double helix plate screw piles

\section{Conclusions}

The current experimental study can be summarized the following points concluded.

- Quick and easy installation, immediate use and other advantages over the conventional pile system have expanded the use of screw piles as a deep foundation for diverse structures.

- The ultimate compressive capacity of screw piles increase with the increasing number of helices.

- The ultimate compressive capacity of screw piles increase with the increasing the depth of embedment in sandy soil.

- The most effective spacing ratio " $\mathrm{S} / \mathrm{Dh}$ " is found to equal to 1 .

- Laboratory results show that the ultimate compression capacity of screw piles is (4-8) times higher than that of ordinary piles depending upon the number of helices.

- The ultimate compressive capacity of screw piles of $\mathrm{S} / \mathrm{Dh}=1.6$ less than for screw pile of $\mathrm{S} / \mathrm{Dh}=1$.

\section{Funding and Acknowledgement}

The financial support from the Ministry of Education and Ministry of High Education and Scientific Research are acknowledged. I would like to thank the head and the staff of Civil Engineering Department, University of Diyala (Iraq) and the staff of Soil Laboratory and Road Laboratory for utilizing their laboratories. Sincere gratitude to my supervisor, Assist. Prof. Dr. Hassan Obaid Abbas for his valuable advices, and giving their expansive time throughout the preparation of this work.

\section{Conflicts of Interest}

The authors declare no conflict of interest.

\section{References}

[1] Brand, E. W. and Brenner, R. P., "Soft Clay Engineering." Developments in Geotechnical Engineering (1981). doi:10.1016/c2009-0-14508-7.

[2] British Standard B.S: C.P. 8004, "Code of Practice for Foundations”, British Standard Institution, London, British, (1986). doi:10.3403/00159525.

[3] Firoozi, Ali Akbar, C. Guney Olgun, Ali Asghar Firoozi, and Mojtaba Shojaei Baghini. "Fundamentals of Soil Stabilization." International Journal of Geo-Engineering 8, no. 1 (December 2017). doi:10.1186/s40703-017-0064-9. 
[4] Ascalew, A., and G. N. Ian Smith. "Pile Foundation Design: A Student Guide." School of the Built Environment, Napier University, Edinburgh. Balkema/Rotterdam/Boston (2007): 83-102.

[5] Basu, Prasenjit, and Monica Prezzi. "Design and Applications of Drilled Displacement (Screw) Piles", Publication FHWA/IN/JTRP-2009/28., Joint Transportation Research Program, Indiana Department of Transportation and Purdue University, West Lafayette, Indiana. (1969). doi:10.5703/1288284314278.

[6] Fahmy, Ahmed, and M. Hesham El Naggar. “Axial Performance of Helical Tapered Piles in Sand.” Geotechnical and Geological Engineering 35, no. 4 (February 22, 2017): 1549-1576. doi:10.1007/s10706-017-0192-1.

[7] Likhitha.H1, Raghavendra.H.N2, Rakesh.K.P3 and Uday Shrihari.P. "The Compression Bearing Capacity of Helical Piles in Black Cotton Soil.” International Journal of Innovative Research in Science, Engineering and Technology Vol. 6, Issue 7, (July 2017).

[8] Hassan Obaid Abbase. Pullout Capacity of Screw Piles in Sandy Soil. Journal of Geotechnical Engineering. 2017; 4(1): 8-12p.

[9] Albusoda, Bushra S., and Hassan O. Abbase. "Performance Assessment of Single and Group of Helical Piles Embedded in Expansive Soil.” International Journal of Geo-Engineering 8, no. 1 (December 2017). doi:10.1186/s40703-017-0063-x.

[10] Wang, Tengfei, Jiankun Liu, Bowen Tai, Chuanzhen Zang, and Zhichun Zhang. "Frost Jacking Characteristics of Screw Piles in Seasonally Frozen Regions Based on Thermo-Mechanical Simulations." Computers and Geotechnics 91 (November 2017): 27-38. doi:10.1016/j.compgeo.2017.06.018.

[11] Hargrave, R. L., and R. E. Thorsten. "Helical piers in expansive soils of Dallas, Texas." In Proceedings of the 7th International Conference on Expansive Soils, Dallas, Tex, pp. 3-5. 1992.

[12] Geotechnics, Arup. "Design of screw piles: assessment of pile design methodology." Ove Arup \& Partners Ltd, London (2005).

[13] Livneh, Ben, and M. Hesham El Naggar. "Axial Testing and Numerical Modeling of Square Shaft Helical Piles under Compressive and Tensile Loading.” Canadian Geotechnical Journal 45, no. 8 (August 2008): 1142-1155. doi:10.1139/t08-044.

[14] Khazaei, Javad, and Abolfazl Eslami. "Geotechnical Behavior of Helical Piles via Physical Modeling by Frustum Confining Vessel (FCV)." International Journal of Geography and Geology 5, no. 9 (2016): 167-181. doi:10.18488/journal.10/2016.5.9/10.9.167.181.

[15] Al-Baghdadi, Therar A., Michael J. Brown, Jonathan A. Knappett, and Asad H. Al-Defae. "Effects of Vertical Loading on Lateral Screw Pile Performance." Proceedings of the Institution of Civil Engineers - Geotechnical Engineering 170, no. 3 (June 2017): 259-272. doi:10.1680/jgeen.16.00114.

[16] Hamed, Majid, Hanifi Canakci, and Omar Khaleel. "Performance of Multi-Helix Pile Embedded in Organic Soil under Pull-Out Load.” Transportation Infrastructure Geotechnology 6, no. 1 (January 9, 2019): 56-66. doi:10.1007/s40515-018-00069-0.

[17] Mohajerani, Abbas, Dusan Bosnjak, and Damon Bromwich. “Analysis and Design Methods of Screw Piles: A Review.” Soils and Foundations 56, no. 1 (February 2016): 115-128. doi:10.1016/j.sandf.2016.01.009.

[18] Al-Baghdadi, TA, C Davidson, MJ Brown, JA Knappett, A Brennan, C Augarde, W Coombs, L Wang, D Richards, and A Blake. “CPT-Based Design Procedure for Installation Torque Prediction for Screw Piles Installed in Sand.” Offshore Site Investigation Geotechnics 8th International Conference Proceedings (n.d.): 346-353. (2018) doi:10.3723/osig17.346.

[19] British Standards Institution, BSI, BS 8004, (2015), Code of Practice for Foundations, Milton Keynes, London, British.

[20] Sakr, Mohammed. "Installation and Performance Characteristics of High Capacity Helical Piles in Cohesionless Soils." DFI Journal - The Journal of the Deep Foundations Institute 5, no. 1 (June 2011): 39-57. doi:10.1179/dfi.2011.004.

[21] Zhang, D. J. Y., R. Chalaturnyk, P. K. Robertson, D. C. Sego, and G. Cyre. "Screw Anchor Test Program (Part I): Instrumentation, Site Characterization and Installation." In Proc. 51 st Canadian Geotech. Conf., Edmonton. 1998.

[22] Abdel-Rahim, Hamdy HA, Yehia Kamal Taha, and Walla El din El sharif Mohamed. "The compression and uplift bearing capacities of helical piles in cohesionless soil." Journal of Engineering Sciences 41, no. 6 (2013): 2055-2064. 